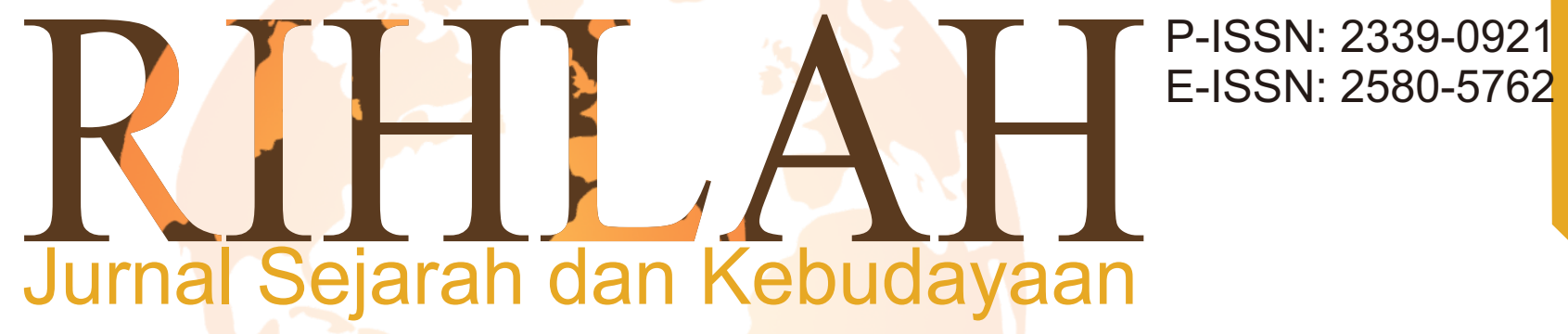

Sejarah Diaspora Suku Bugis-Makassar di Kalimantan Tengah Suryanti, Ihsan Mz, ST. Rahmah

Kearifan Lokal Handep Masyarakat Dayak: Perspektif Cendekiawan Muslim Dayak di IAIN Palangka Raya Muhammad Husni

Tradisi Masyarakat Islam Melayu Jambi: Perspektif Pierre Bordieau Aliyas, Benny Agusti Putra

Tradisi Mappande Sasi' pada Masyarakat Tangnga-tangnga Kabupaten Polewali Mandar (Unsur Budaya Islam) Nurannisa, Ahmad M. Sewang, Wahyuddin G

Implementasi Ritual Addinging-dinging pada Masyarakat Modern di Tambung Batua Gowa: Tinjauan Sosio-Kultural)

Mastanning, Khadijah Tahir, Abdullah Renre

Iran pada Masa Reza Syah 1925-1941

Faiz Nasrullah

Penyebaran Pendidikan Islam di Buol Abad XX M.

Muhammad Nur Ichsan Azis, Salmin Djakaria 


\section{RIHLAH}

\section{Jurnal Sejarah dan Kebudayaan}

\begin{tabular}{|l|l|}
\hline Editor in Chief & $:$ Dr. Rahmat, M.Pd. \\
\hline Managing Editor & $:$ Nurlidiawati, S.Ag., M.Pd. \\
\hline Editors & $:$ Prof. Dr. Mardan, M.Ag. \\
$:$ Dr. Zaenal Abidin, SS., M.Hi. \\
$:$ Dr. Lydia Megawati, M.Hum. \\
$:$ Mastanning, M.Hum. \\
$:$ Aksa, M.Pd. \\
$:$ Chaerul Munzir, M.Hum. \\
$:$ Muhammad Arif, M.Hum. \\
$:$ Misbahuddin, M.Hum. (IAIN Ternate) \\
\hline Editorial Board & $:$ Dr. Syamhari, M.Pd. \\
$:$ Dra. Hj. Surayah, M.Pd. \\
$:$ Nur Ahsan Syakur, S.Ag., M.Si. \\
$:$ Chusnul Chatima Asmad, S.S., M.Hum. \\
$:$ Saepuddin, M.Ag. (STAIN Riau) \\
$:$ Iqbal, M.Hum. \\
$:$ Miftahuddin (Universitas Negeri Yogyakarta) \\
\hline Secretariat
\end{tabular}




\begin{tabular}{|l|l|}
\hline Reviewers & $:$ Prof. Dr. H. Abd. Rahim Yunus, M.A. \\
$:$ Prof. Dr. H. Ahmad M. Sewang, M.Ag. \\
$:$ Prof. Dr. H. M. Dahlan M., M.Ag. \\
$:$ Prof. Dr. H. Hasaruddin, M.Ag. \\
$:$ Dr. Wahyuddin, G., M.Ag. \\
$:$ Dr. Susmihara, M.Pd. \\
$:$ Dr. Hj Syamzan Syukur, M.Ag. \\
$:$ Dr. Rahmawati, M.A. \\
$:$ Dr. Abu Haif, M.Hum. \\
$:$ Dr. Nasruddin, M.M. \\
$:$ Dr. Abd. Rahman Hamid. (UNHAS) \\
$:$ Dr. Nurhayati Syairuddin, M.Hum. \\
(UNHAS) \\
$:$ St. Junaeda, S.Ag., M.Pd., M.A. (UNM) \\
$:$ Nasihin, S.S., M.A. (UNM) \\
$:$ Ahmad Abbas Musofa (IAIN BENGKULU) \\
$:$ Arafah Pramasto (Dinas Sosial Kota \\
Palembanga)
\end{tabular}

Alamat Redaksi dan Tata Usaha : Jurusan Sejarah dan Kebudayaan Islam Fakultas Adab dan Humaniora UIN Alauddin Makassar, Jln. Sultan Alauddin No. 36 Samata Gowa Tlp. 0411-841879 Fax.0411-822140 (Kampus II) E.Mail. rihlah@uin-alauddin.ac.id

Jurnal Rihlah terbit dua kali dalam setahun, bulan Juni dan bulan Desember berisi kajian tentang Sejarah dan Kebudayaan, baik dari hasil penelitian maupun tulisan ilmiah lainnya.

Penyunting menerima tulisan yang belum pernah diterbitkan oleh media cetak lain. Naskah diketik spasi $1 \mathrm{~cm}$ pada kertas berukuran A4 dengan tulisan berkisar 10-23 halaman. Naskah yang masuk dievaluasi oleh Dewan Penyunting. Penyunting dapat melakukan perubahan pada tulisan yang dimuat untuk keseragaman format, tanpa mengubah maksud dan konten tulisan. 


\section{DAFTAR ISI}

Suryanti, Ihsan Mz, ST. Rahmah

$100-112$

Sejarah Diaspora Suku Bugis-Makassar di Kalimantan Tengah

Muhammad Husni.

$113-133$

Kearifan Lokal Handep Masyarakat Dayak: Perspektif Cendekiawan

Muslim Dayak di IAIN Palangka Raya

Aliyas, Benny Agusti Putra....

$134-144$

Tradisi Masyarakat Islam Melayu Jambi: Perspektif Pierre Bordieau

Nurannisa, Ahmad M. Sewang, Wahyuddin $G$

$145-156$

Tradisi Mappande Sasi' pada Masyarakat Tangnga-tangnga

Kabupaten Polewali Mandar (Unsur Budaya Islam)

Mastanning, Khadijah Tahir, Abdullah Renre

$157-175$

Implementasi Ritual Addinging-dinging pada Masyarakat Modern

di Tambung Batua Gowa: Tinjauan Sosio-Kultural

Faiz Nasrullah

$176-187$

Iran pada Masa Reza Syah 1925-1941

Muhammad $\mathcal{N}$ ur Ichsan Azis, Salmin Djakaria

$188-200$

Penyebaran Pendidikan Islam di Buol Abad XX M. 


\title{
Penyebaran Pendidikan Islam di Buol Abad XX M
}

\author{
Muhammad Nur Ichsan Azis, Salmin Djaķaria \\ Balai Pelestarian Nilai Budaya Sulawesi Utara \\ icchankazis18@gmail.com \\ dj2salmin@gmail.com
}

\begin{abstract}
This paper describes the process of spreading Islamic education in Buol towards the beginning of the 20th century. Islamic education is in Buol through the role of preachers and propagators of Islam who come to Buol through maritime trade routes. By using historical, heuristic, criticism, interpretation, and historiography methods, as well as a social science approach. Islamic education in Buol cannot be separated from the spreaders of Islam through the da'wah network where they also influence the development of Islamization. In Buol, Islamic education is found through the path of Sufism, and also politics by the appointment of a kadi. In addition, Islamic education developed because of the role of the aristocracy who wanted to make changes to Buol in the early 20th century. They developed education by learning from several teachers and scholars, and they also studied in several developing areas in the archipelago in the early 20th century.
\end{abstract}

Keyword: History, Development, Islamic, Education

\section{Abstrak}

Tulisan ini mendeskripsikan proses penyebaran pendidikan Islam di Buol menjelang awal abad ke-20. Pendidikan Islam di buol berporses melalui peran para pendakwah dan penyebar Islam yang datang ke Buol melalui jalur niaga maritim. Dengan menggunakan metode sejarah, heuristik, kritik, interpretasi dan historiografi, serta pendekatan ilmu sosial. Pendidikan Islam di Buol tidak lepas dari peran para penyebar Islam melalui jaringan dakwah dimana mereka juga berpengaruh pada perkembangan Islamisasi. Di Buol, pendidikan Islam ditemukan melalui jalur tasawuf, dan juga politik dengan diangkatnya seorang kadi. Selain itu juga, pendidikan Islam berkembang karena peran dari kalangan bangsawan yang ingin melakukan perubahan atas Buol di awal abad ke20. Mereka mengembangkan pendidikan dengan cara belajar ke beberapa guru dan ulama, serta mereka juga belajar ke beberapa daerah berkembang di Nusantara pada awal abad ke-20.

Kata Kunci: History, Perkembangan, Pendidikan, Islam

\section{Pendahuluan}


Perjalanan panjang pendidikan di Indonesia berpengaruh pada berbagai aspek di masyarakat. Perkembangan pendidikan kemudian berdampak pada proses persebaran dan corak pendidikan Islam. Di daratan Buol, perkembangan pendidikan Islam memiliki keunikan dari periodisasi waktu mengalami keterlambatan, para guru, dan juga murid-murid yang menjadi aktor utama di dalamnya. Pendidikan Islam berkaitan erat dengan ciri khas kebudayaan yang berkembang di masyarakat. Seperti halnya yang terjadi di Sumatera yang dikenal dengan surau, dan dayah, dan di Jawa terdapat pesantren sebagai ruang perkembangan pendidikan Islam di masa awal sehingga pada masa berikutnya pendidikan Islam yang mampu bermetamorfosa berdasarkan zamannya.

Berdasarkan catatan sejarah, perkembangan pendidikan Islam tidak lepas dari gerakan dakwah dari para penyebar Islam yang masuk ke Nusantara sejak abad ke-13 M di Nusantara. Steenbrink ${ }^{1}$ mengungkapkan bahwa pendidikan Islam di Indonesia tidak lepas dari proses historis yang berhubungan dengan dunia pesantren, dan warisan kebudayaan Hindu-Buddha, sehingga berdampak pada corak pendidikan Islam di masa modern. Lebih jauh lagi, pendidikan Islam memiliki tujuan dan fungsi dari yang secara perlahan mengalami berubah. Proses ini mengarah pada modernisasi pendidikan Islam yang sesuai dengan perkembangan zaman, namun di satu sisi metode pendidikan Islam memiliki ciri khas yang tetap dipertahankan².

Para pedagang dan penyebar Islam menjadi salah satu aktor penting dalam pengenalan transformasi keislaman dan pendidikan Islam melalui metode dakwah yang terjadi di Nusantara secara umum pada rentan abad ke-16 hingga ke-19 M. Dinamika ini terjadi beriringan dengan perkembangan jalur dan lalu lintas niaga, dan proses penyebaran Islam. Perpindahan yang sering terjadi berdampak pada proses pembentukan ruang pendidikan dan hal tersebut memuncak pada abad ke-19 M. Meski demikian, persoalan wilayah juga menjadi salah satu faktor penentu berkembangnya pendidikan Islam.

Di daratan Buol, pendidikan Islam memiliki keterikatan antara kegiatan niaga dan para penyebar Islam, serta relasi politik niaga antara Buol dan pemerintah kolonial. Beberapa pedagang Muslim dari wilayah lain terlibat aktif dalam proses pembentukan pendidikan Islam. Di sisi lain, ketika pendidikan Islam semakin berkembang pada abad ke-19 M, Buol justru mengalami keterlibatan politik yang

\footnotetext{
${ }^{1}$ Karel A. Steenbrink, Pesantren, Madrasah, dan Sekolah: Pendidikan Islam dalam Kurun Modern, Terj. Karel A. Steenbrink dan Abdurrahman, (Jakarta: LP3ES, 1994).

${ }^{2}$ Azyumardi Azra, Pendidikan Islam: Tradisi dan Modernisasi Menuju Milenium Baru, (Jakarta: Logos, 1999), h. 4-5; Azyumardi Azra, Surau, Pendidikan Islam Traidisional dalam Transisi dan Modernisasi, (Jakarta: Logos, 2003), h. 1-3.
} 
menyebabkan terjadinya konflik antara masyarakat Muslim dan pemerintah kolonial. Akibat dari konflik tersebut, pendidikan Islam di Buol mengalami keterbatasan, berdasarkan catatan sejarah, memiliki "potensi radikalisme" yang terbentuk dalam lembaga pesantren atau madrasah. Bahkan lebih jauh lagi, inklusivitas pendidikan Islam mampu menghambat perkembangan dunia pendidikan ${ }^{3}$.

Kondisi pendidikan Islam di daratan Buol tidak dapat disamakan dengan kondisi pendidikan Islam di Jawa dan Sumatera. Pendidikan Islam di Jawa dan Sumatera berkembang progresif dengan banyaknya ulama dan para guru yang menjadi rujukan. Di sisi lain, perkembangan pendidikan Islam di Jawa dan Sumatera semakin berkembang disebabkan oleh para tokoh dan pemikir Muslim modern yang juga berkembang sampai pada abad ke-20 M. Sedangkan Buol pada awal abad ke-20 masih berusaha membangun dunia pendidikan Islam karena keterbatasan guru dan ulama, sehingga ditemukan beberapa tokoh masih memiliki keterkaitan dengan guruguru dari Jawa dan Sumatera.

Hubungan guru-murid secara tidak langsung berdampak pada perkembangan pendidikan Islam di Buol seperti yang dilakukan Dato Karema, Syekh Yusuf alMaqassari, pada abad ke-17, dan Syarif Ali, serta anaknya Syarif Mansur pada abad ke-19 M. Poros perkembangan pendidikan tidak dapat dilepaskan pada dua faktor utama yakni internal dan eksternal. Pada faktor internal para penyebar Islam, guru, dan masyarakat Muslim berperan penting pada arus pembentukan pendidikan Islam. Sedangkan pada faktor eksternalnya, pembagian sentralisasi dan desentralisasi pendidikan memicu kebijakan dan arah pendidikan Islam.

Persoalan pendidikan tidak pernah ada habisnya untuk selalu dikaji dan diteliti. Pendidikan Islam terus mengalami perkembangan dengan nilai dan ciri khasnya. Perkembangan ini didukung oleh faktor globalisasi dan modernisasi pemikiran Kajian ini perkembangan pendidikan Islam di Buol dengan menggunakan metode historis; heuristik, kritik, interpretasi dan historiografi. Perkembangan pendidikan Islam secara siginifikan terjadi ketika modernisasi pendidikan dilakukan dengan memasukkan materi umum dalam kurikulum pendidikan Islam untuk mengikuti perkembangan zaman dan cara berpikir masyarakat modern.

\section{Sejarah Kawasan Buol}

Dalam tradisi lisan, oral history, dan ingatan bersama, memory collective, masyarakat Buol, keberadaan Buol tidak lepas dari cerita leluhur mereka. Dikisahkan bahwa Tomatau dan Buki Kunimilato merupakan leluhur penduduk Buol masa kini.

\footnotetext{
${ }^{3}$ Azyumardi Azra, "Pendidikan Islam di Era Globalisasi: Peluang dan Tantangan”, dalam Junral Penelitian Pendidikan Agama dan Keagamaan, vol. 6, No. 4 (2008), h. 128.
} 
Mereka merupakan sepasang suami-istri yang kemudian memiliki dua anak yakni Donolangit dan Kotingi. Donolangit kemudian memiliki keturunan bernama Ombu Kilano yang kemudian dikenal sebagai pendiri pertama Kerajaan Buol. Pada kisah lainnya, masyarakat juga menghubungkan dengan Bwulaatu Bwulaano dan Tomuang Bwulaano yang memiliki keturunan bernama Manurung hingga membentuk masyarakat Buol. ${ }^{4}$ Dalam sumber lain juga mengisahkan asal-usul orang Buol berkaitan dengan Sawerigading ${ }^{5}$ sebagai leluhur mereka.

Adapun informasi lainnya yang dikisahkan adalah Gunung Pogogul sebagai tempat awal mereka berada di Buol. Menariknya, kisah tersebut masih diyakini hingga sekarang dan tidak lepas dari seorang tokoh bernama Tilo Ombu Kilano yang membuka wilayah baru di sekitar pesisir sungai yang dipimpin langsung oleh Donolangit. Donolangit yang berdiam di Gulamonial memiliki empat keturunan, yang pada masa berikutnya menjadi kerajaan independen. Awal mula dari berdirinya Buol tidak lepas dari independensi para kepula suku yang memimpin rakyatnya. Keturunan dari Ombu Kilan, Donolangit, membagi wilayah kepada anaknya masingmasing di Biau, Tongon, Talaki, dan Bonobogu ${ }^{6}$.

Tiga kisah di atas memiliki informasi yang tersirat bahwa keberadaan daratan dan masyarakat Buol tidak lepas dari peristiwa kosmologis. Alam dan tokoh sentral menjadi tolak ukur untuk mengindentifikasi perkembangan masyarakat setempat. Di sisi lain, kedatangan para bajak laut Mangindanao juga mempengaruhi perkembangan masyarakat Buol. Di masa kerajaan tradisional, Buol juga pernah ditaklukkan oleh penguasa Sigi, dan menawan seorang pemimpin lokal, Tamodoka, yang dibawa ke Sigi ${ }^{7}$. Kisah tersebut terus bertahan dan berkembang dalam keseharian masyarakat Buol, sebelum masuknya pengaruh asing.

Keberadaan para pedagang asing mempengaruhi keadaan Buol di masa kemudian. Pada abad ke-17 M, terbentuk jalur Islamisasi di Buol yang dibawa oleh para pedagang yang berdiaspora ke kawasan strategis. Mereka menempatkan Buol, sebagai daerah transit menuju Maluku, hingga membentuk sebuah pemukiman sementara di pesisir muara Sungai Buol. Fase awal pembentukan jalur islamisasi di Buol beriringan dengan proses perkembangan Islam di kawasan lainnya hingga pada

${ }^{4}$ Data ini diperoleh dari Focus Group Discussion, FGD yang dilakukan di Buol pada tanggal 16 Maret 2020.

${ }^{5}$ Legenda Sawerigading berhubungan dengan kisah masyarakat Sulawesi Selatan sebagai leluhur. Di samping itu, Sawerigading, dalam naskah I Laga Ligo berhubungan erat dengan perjalanan menuju daratan Cina pada abad ke-13 M.

${ }^{6}$ T. Kawandaud, Tambo dan Sejarah Buol, (Gorontalo: Drukkerij Annaser), h. 5-10.

7 Tim Proyek Inventarisasi dan Dokumentasi Kebudayaan Daerah, Sejarah Daerah Sulawesi Tengah, (Jakarta: Depdikbud, 1984), h. 27. 
abad ke-19 M. Alasan ini didasari melalui asumsi bahwa masyarakat Buol yang berinteraksi dengan para pedagang Muslim perlu melakukan adaptasi, dan berdampak pada usaha pembentukan peradaban dan kebudayaan yang saling mempengaruhi. Salah satu pengaruh awal terlihat pada bidang pendidikan bahwa praktek beragama dari animis dan dinamis perlahan berubah dengan menjalankan ajaran Islam. Warisan peradaban Islam, terutama pada bidang pendidikan, berdampak pada munculnya lembaga semi-formal yang melibatkan para pelaku tarekat dan guru sufi hingga pada abad ke-19 M.

Titik balik pendidikan Islam di Buol terjadi pada pertengahan abad ke-17 M di masa pemerintahan Sultan Eyato (1673-1679). Raja Eyato memberi penghargaan tinggi terhadap pendidikan, sehingga dengan pendidikan dapat mengangkat status sosial dan kecenderungan menggeser struktur sosial golongan wali-wali (keturunan bangsawan). Sebelumnya status sosial ditentukan dari garis darah dan keturunan. Eyato kemudian melakukan pembaharuan dengan dasar utama pendidikan, agama, dan akhlak bisa menduduki posisi dalam birokrasi pemerintahan dalam kerajaan.

Pada kasus Buol, saluran dan jalur islamisasi mungkin dapat kita bagi menjadi empat media, meskipun secara umum ada enam saluran islamisasi yang ditawarkan oleh para akademisi dan pengkaji sejarah. Penulis berkesimpulan, melalui sumber yang diperoleh, bahwa keempat saluran tersebut adalah perdagangan, politik, pernikahan, serta tasawwuf; pendidikan dan kesenian masuk ke dalamnya.

Tidak hanya melalui saluran tasawwuf, dua saluran lain juga memiliki hubungan erat dengan jalur tasawuf yakni pendidikan dan kesenian. Proses islamisasi dari saluran tasawwuf lambat laun berkembang semakin luas yang kemudian berkembang dan bertransformasi menjadi wadah pendidikan non-formal. Dalam konteks ini akan ditemukan sebuah jejaring guru-murid yang menopang perkembangan dan pemertahanan Islam di suatu wilayah. Di Sulawesi Tengah, termasuk Buol, ditemukan dua tokoh penyebar Islam yakni Dato Karama, Abdul Raqie, dan Dato Mangadji yang berperan besar pada eksistensi Islam di daratan Sulawesi Tengah. Di sisi lain, hubungan Buol dengan Gorontalo juga menunjukkan bahwa tasawuf yang berkembang di Gorontalo berpengaruh ke Buol. Raja Gorontalo, Sultan Amai, melakukan pengembangan dunia da'wah Islam dengan menjalankan syariat Islam, bahkan dia juga mengangkat guru yang didatangkan dari wilayah Palasa ${ }^{8}$ yang bertugas mengislamkan dan membimbing penduduk lokal ${ }^{9}$. Mereka mengajarkan Islam melalui pengenalan tasawuf, dan juga mengajarkan

\footnotetext{
${ }^{8}$ Richard Tacco, Het Volk van Gorontalo: Historisch Traditional Maatschappelijk Cultural Sociaal Karakteristiek en Economisch, (Gorontalo: Gorontalo Drukkerij, 1935), h. 26.

9 S. R. Nur, Beberapa Aspek Hukum Adat Tata Negara Kerajaan Gorontalo Pada Masa Pemerintahan Eato 1673-1679, (Ujung Pandang: Universitas Hasanuddin, 1979), h. 21.
} 
membaca dan menulis aksara Arab. Metode yang digunakan yakni dengan sistem khalaqah dimana para murid duduk mengelilingi guru. Metode secamam ini terbilang efektif untuk mengajar sebab guru dan murid berhadapan langsung, sehingga guru dan murid dapat langsung berinteraksi, serta memudahkan transfer keilmuan.

\section{Peran Penyebar Islam dan Guru di Masa Awal}

Catatan literatur menunjukkan bahwa pengaruh para penyiar Islam di Buol berdampak positif. Dua tokoh penyebar Islam di kawasan Sulawesi Tengah, Dato Karama dan Dato Mangadji, pada abad ke-17 M mengindikasikan bahwa ajaran Islam memasuki periode awal dalam islamsasi di Sulawesi Tengah ${ }^{10}$. Di daratan Buol, hubungan Dato Karama dan Dato Mangadji dihubungkan dengan kondisi yang terjadi di Pulau Sulawesi secara umum.

Tiga ulama Minangkabau di Sulawesi Selatan, Dato ri Bandang, Dato ri Tiro, dan Dato ri Pattimang, disebut-sebut memiliki relasi dengan dua ulama tersebut. Kemungkinan tersebut dapat dilihat pada asal dan masa kedatangan mereka di daratan Sulawesi. Selanjutnya, kita dapat melihat hubungan politis antara Sultan Aceh dengan para penguasa lokal di kawasan Timur Nusantara, termasuk hubungan Aceh-Makassar, ataupun Aceh-Ternate, melalui para utusan yang dikirimkan untuk menyebarkan ajaran Islam.

Kedatangan mereka pertama kali di daratan Sulawesi di perkuat melalui hubungan Luwu ${ }^{11}$ dan berpencar ke daerah-daerah tujuan mereka. Dato Karama, sebagaimana dalam tradisi lisan diceritakan, pernah terdampar di Lembah Palu, Karampe. Hubungan lainnya adalah para ulama dari Minangkabau juga memiliki relasi dengan ulama bernama Syarif Makhdum yang ternyata seorang Pangeran Sumatera $^{12}$.

Tidak hanya melalui pengaruh politik, pengaruh ekonomi juga turut berpengaruh dalam perkembangan pendidikan Islam di Buol. Seorang pedagang, sekaligus penyebar Islam, bernama Syarif Ali terlibat langsung dalam aktivitas niaga dan penyebaran Islam di daratan Buol. Dalam tradisi lisan masyarakat Buol, Syarif Ali dikenal memiliki keutamaan yakni melakukan perjalanan dari Sulawesi ke

${ }^{10}$ Sadi, Haliadi, dan Syamsuri, Sejarah Islam di Lembah Palu, (Yogyakarta: Q Media, 2016), h. $42-43$.

${ }^{11}$ Abu Hamid, "Sistem Pendidikan Madrasah dan Pesantren di Sulawesi Selatan" dalam Taufik Abdullah ed., Agama dan Perubahan Sosial, (Jakarta: CV. Rajawali, 1983), h. 339-340.

${ }^{12}$ Azyumardi Azra, Surau, Pendidikan Islam Traidisional dalam Transisi dan Modernisasi, (Jakarta: Logos, 2003), h. 11; Majul, Cesar A., 1989. Dinamika Islam di Filipina, (Jakarta: LP3ES), h. 9-10. 
Makkah dalam waktu singkat ${ }^{13}$. Dia juga seorang ulama yang memiliki relasi dengan Aceh di masa akhir hayatnya.

Dia, Syarif Ali, diperkirakan mengunjungi Buol sekitar 1825 M, melalui Mandar. Dia menjadi seorang saudagar yang dikenal sebagai pemilik modal dan beberapa kapal untuk berniaga komoditas niaga rempah. Setibanya di Buol, Syarif Ali para pedagang Muslim Mandar bergerak menyebarkan Islam melalui pengaruh ekonomi.

Anak dari Syarif Buol, Syarif Mansur, melanjutkan perannya sebagai penyebar Islam di Buol. Dia dikenal sebagai 'tuan Arab', sekaligus guru dan ulama di Buol. Ajaran utama yang disebarkan adalah tasawuf dan tarekat kepada penduduk Muslim Buol. Bahkan dia menjadi pemimpin gerakan perlawan terhadap kolonial di Manado pada tahun $1875 \mathrm{M}$, namun tidak berhasil. Akan tetapi pengaruhnya tetap bertahan melalui jejaring pendidikan, termasuk di Bintauna, yang dikenal sebagai guru Islam.

Nama lain yang berpebngaruh dalam perkembangan pendidikan Islam di Buol adalah Sayyid Zain al-Idrus yang juga terlibat langsung dalam penyebaran Islam, dan perkembangan pendidikan Islam di Buol. Dia sempat diangkat menjadi Qadhi di pemerintahan Kerajaan Buol hingga akhir abad ke-19 dan awal abad ke-20 M. Dampak dari pengangkatan tersebut ialah dia berhasil mengajarkan ilmu syariat dan tasawwuf dan kembali memperkokoh posisi umat Islam di Buol hingga sekarang ini.

\section{Awal Pembentukan Pendidikan Islam di Buol Awal Abad ke-20 M}

Perkembangan pendidikan Islam di Buol berjalan beriringan dengan petumbuhan penduduk Muslim di kawasan tersebut. Pengaruh para muballig di akhir abad ke-19 M, meninggalkan jejak melalui akar dan posisi ke-Islam-an di Buol yang semakin menguat. Pada akhir abad ke-19 M, pendidikan Islam pertama kali diselenggarakan melalui rumah para guru, mushalla, hingga masjid dengan membentuk majlis dan halaqah. Pada masa itu pula terjadi gerakan arus pemikiran Islam yang berdampak pada ketertarikan kalangan bangsawan Muslim Buol untuk mendalami Islam. Akar ke-Islam-an melalui gerakan pendidikan kemudian terbentuk dengan gerakan pemikiran 'Islam Modern'. Para bangsawan Buol pada awalnya bersekolah di lembaga pendidikan milik pemerintah kolonial yang ada di Gorontalo dan Manado. Dan tidak jarang di antara mereka juga melanjutkan pendidikan ke Jawa dan daerah lainnya.

${ }^{13}$ Lopez, Ariel C., "Conversion and Colonialism: Islam and Chrsitianity in North Sulawesi, c. 1700-1900", Proefschrift ter ter verkrijging van de graad van Dotro aan de Universiteit Leiden, (Filipina, Lucena City, 2018), h. 97-98; Van Andel, W. J. D., Memory van Overgave, MVO, No. 39, onderafdeeling Buol, 27 Juli 1917. 
Selain para elite bangsawan, para keturunan para pedagang dan pendatang yang sukses juga ikut terlibat dalam proses pendidikan Islam di Buol. Mereka belajar langsung kepada guru dan ulama Arab, seperti Syarif Mansur atau saudaranya di Gorontalo. Mereka juga terlibat dalam pembentukan pemikiran Islam Modern di masyarakat Muslim Buol pada awal abad ke-20 M. Relasi mereka terbangun melalui hubungan guru-murid yang kemudian menyebar ke beberapa daerah strategis, seperti Jawa, Makassar, Gorontalo, hingga Manado. Meski demikian, proses ini berjalan cukup lambat karena relasi guru-murid dan penyebar Islam yang samar dalam struktur masyarakat Buol. Beberapa di antara mereka lebih dikenal sebagai saudagar dibandingkan dengan ulama, sehingga mereka lebih banyak dikenal dengan istilah "tuan Arab".

Keterlibatan para guru dan ulama Arab dalam gerakan tarekat semakin menguatkan bahwa terjadi pengaruh kuat dalam kehidupan keagamaan dan pendidikan Islam. Dunia pendidikan yang mereka praktekkan diawali dari pendidikan non-formal dimana mengajarkan teks-teks keagamaan secara tekstual, seperti mengeja, membaca, hingga mampu mengaji al-Qur'an. Keterlibatan dan peran para ulama tidak berorientasi pada pendidikan formal, namun lebih berorientasi pada pemaknaan dan penghayatan ajaran ke-Islam-an yang dapat dipraktekkan secara tekstual dan kontekstual. Hal ini dibuktikan melalui praktek kolaboratif dalam memaknai ajaran Islam yang memadukan antara tradisi keilmuan dalam Islam dan kondisi masyarakat.

Di Buol, pengajaran pendidikan Islam, yang paling utama adalah persoalan syariat, dan akidah, yang direpresentasikan melalui praktek sehari-hari masyarakatnya. Namun yang menjadi persoalan adalah keterbatasan guru dan ulama yang mengajarkan Islam. Keterikatan tersebut kemudian berdampak pada beberapa tingkatan di pemerintahan. Selain adanyanya qadhi, petugas syara' juga ditunjuk dari kalangan murid yang dianggap mumpuni dan memahami ajaran Islam dengan baik. Hanya saja perkembangan pendidikan Islam di Buol kemudian menghadapi kendala ketika pendidikan formal yang kembali dihidupkan oleh pemerintah kolonial melalui kebijakan politik etis di awal abad ke-20.

Sebagaimana yang telah dijelaskan di atas, beberapa kalangan bangsawan lebih memilih bersekolah di sekolah formal yang didirikan oleh pemerintah kolonial, dan pengajaran Islam mengalami kemunduran yang hanya kemudian bertahan melalui praktek ritual tasawuf dan tarekat.

\section{Perkembangan Pendidikan Islam di Buol Abad ke-20 M}

Dalam kasus Nusantara di awal abad ke-20 M, kebijakan politik etis sebenarnya membawa sisi positif bagi masyarakat. Pemerintah kolonial menjanjikan 
masyarakat bumi putera untuk berdaya dan berdikiari pada tiga hal yakni edukasi, irigasi, dan transmigrasi. Namun, secara spesifik hal tersebut justru berpengaruh pada perkembangan pendidikan Islam di Nusantara. Munculnya sistem pendidikan formal dengan strata kelas, kemudian menyingkirkan pendidikan dengan basis keagamaan. Misalnya dalam dunia pesantren, praktek pendidikan dikhususkan hanya mempelajari 'agama' dengan kurikulum yang kurang jelas. Intinya anak-anak dari kalangan Muslim hanya dibebankan agar dapat membaca, dan mengjai alQur'an. Atau Secara tegas, pendidikan Islam menjadi pilihan "kedua" akibat dari diskriminasi sistem pendidikan formal yang didirikan oleh pemerintah kolonial, yang juga berlanjut menjadi sistem nasional secara keseluruhan ${ }^{14}$.

Praktek pendidikan Islam sejak akhir abad ke-19 dan menjelang awal abad ke-20 M sebenarnya berada pada jalur yang baik. Beberapa akademis Belanda, Holle, Hurgronje, hingga Hazeu mengindikasikan bahwa umat Muslim sedang mengalami kecenderungan era 'kebangkitan kembali'. Pengajaran dan metode pendidikan perlahan berubah dari hafalan ke pemahaman teks, kemudian para guru agama Islam terlihat siap sebagai pendidik dan pengajar yang membawa perubahan. Meski demikian, mereka juga menyebut bahwa para guru agama Islam dari kalangan santri sebagai kalangan sosial yang amfibius, dua peran sekaligus yakni guru sekolah dan guru agama (katekis) ${ }^{15}$.

Dampak perkembangan dari politik etis, terutama dalam dunia pendidikan, di Buol juga semakin terasa. Pengajaran pendidikan Islam diawali dari mengajarkan mengenal huruf Arab, mengaji dengan metode tudang yang diketahui dari tradisi orang-orang Bugis-Makassar, dan Mandar, serta penafsiran sederhana yang diberikan kepada murid-muridnya, terutama mengenai pengamalan syariat dan akidah agama. Beberapa kalangan bangsawan terlibat aktif di dalam proses belajar mengajar tersebut, hingga beberapa di antara mereka memilih melanjutkan pendidikan Islam di luar daerah, terutama ke Gorontalo, hingga ke Jawa.

Sejak tahun $1890 \mathrm{M}$, pendidikan mulai terasa bagi para kalangan bangsawan ${ }^{16}$. Pembaharuan-pembaharuan dalam dunia pendidikan mulai berlangsung dimana beberapa guru agama dari Gorontalo didatangkan. Kebanyakan dari guru tersebut adalah para penganut tarekat dan kalangan sufi. Perubahan administrasi dan penyelenggaraan politik terjadi di Buol pada awal abad ke-20 M.

${ }^{14}$ Azyumardi Azra, "Pendidikan Islam di Era Globalisasi: Peluang dan Tantangan", dalam Junral Penelitian Pendidikan Agama dan Keagamaan, vol. 6, No. 4 (2008), h. 124.

${ }^{15}$ Steenbrink, Karel A., Kaum Kolonial Belanda dan Islam di Indonesia (1596-1942), Yogyakarta: Gading Publishing, 2017), h. 214.

${ }^{16}$ Tim Proyek Inventarisasi dan Dokumentasi Kebudayaan Daerah, Sejarah Daerah Sulawesi Tengah, (Jakarta: Departemen Pendidikan dan Kebudayaan, 1984), h. 85. 
Buol di masukkan dalam wilayah Onderfdeling Buol dengan ibu kota Buol yang juga berdampak pada perubahan sistem pendidikan di Buol, dan kemudian berubah lagi pada tahun 1938 dimasukkan dalam wilayah Karesidenan Gorontalo ${ }^{17}$.

Di awal abad ke-20 M sikap pemerintah kolonial melunak dengan kebijakan politik etisnya. Sejak tahun-tahun itu terjadi perubahan-perubahan di tengah masyarakat, meskipun masih dalam kontrol pemerintah kolonial. Di Buol, mengikuti wilayah Karesidenan Manado, beberapa sekolah desa didirikan. Dunia pendidikan mulai dibuka untuk para penduduk pribumi dari kelas bawah. Di Karesidenan Manado berdiri sekolah desa, Volkschool, tiga tahun, selain sekolah zending ${ }^{18}$. Pengaruh pendidikan Islam juga berkembang dengan adanya pendidikan formal. Beberapa guru agama Islam dipekerjakan untuk mendidik murid-murid Muslim. Tahun-tahun awal pengaruh pendidikan Islam di Buol muncul dari Karesidenan Gorontalo. Sekolah Rakyat didirikan di Gorontalo, bahkan sekolah tersebut menerima para murid pendatang ke Gorontalo dengan jaminan dari penduduk asli yang dikepalai oleh seorang burger ${ }^{19}$.

Pendidikan Islam semakin berkembang melalui pengaruh oganisasi Islam yang muncul di awal abad ke-20 M. Pengaruh Syarikat Islam pada tahun 1916 yang dibawa oleh para revolusioner dari Jawa ${ }^{20}$. Kemudian Muhammadiyah ikut berpengaruh di Buol melalui Gorontalo yang dibawa oleh Tjami Lamato ${ }^{21}$. Kedua gerakan ini tidak hanya terfokus pada gerakan sosial-ekonomi, namun juga pada perubahan dan modernisasi pendidikan di Buol. Beberapa sekolah negeri yang berdiri di Gorontalo menerima murid-murid dari Buol dan beberapa di antara mereka berhasil menjadi guru.

Melalui pengaruh organisasi Syarikat Dagang Islam, dunia pendidikan juga mengalami perkembangan yang signifikan di Buol. Raja Buol, Raja Binol, pada masa itu diangkat menjadi presiden pengurus organisasi Syarikat Dagang Islam di Buol. Pengangkatan itu juga menunjukkan bahwa gerakan tersebut mengarah ke aktivitas positif. Kedatangan A. Muis ke Buol semakin menambah gairah para anggota

${ }^{17}$ Tim Proyek Inventarisasi dan Dokumentasi Kebudayaan Daerah, Sejarah Daerah Sulawesi Tengah, (Jakarta: Departemen Pendidikan dan Kebudayaan, 1984), h. 95.

${ }^{18}$ L. TH. Manus, Sejarah Pendidikan Daerah Sulawesi Utara, (Jakarta: P3K Depdikbud, 1980) h. 83 .

${ }^{19}$ L. TH. Manus, Sejarah Pendidikan Daerah Sulawesi Utara, (Jakarta: P3K Depdikbud, 1980), h. 100.

${ }^{20}$ Tim Proyek Inventarisasi dan Dokumentasi Kebudayaan Daerah, Sejarah Daerah Sulawesi Tengah, (Jakarta: Departemen Pendidikan dan Kebudayaan, 1984), h. 96-97.

${ }^{21}$ Tim Proyek Inventarisasi dan Dokumentasi Kebudayaan Daerah, Sejarah Daerah Sulawesi Tengah, (Jakarta: Departemen Pendidikan dan Kebudayaan, 1984), h. 97. 
Syarikat Dagang Islam dan para pemuda untuk tetap melakukan perlawanan terhadap kolonialisme ${ }^{22}$.

Hal ini juga sejalan dengan respon yang diberikan masyarakat kepada organisasi Syarikat Dagang Islam yang mendukung penuh anggaran dasar yang ditawarkannya, terutama pada dunia pendidikan dan pengajaran. Organisasi SI mendirikan sekolah untuk kalangan pribumi, dan kemudian mendapatkan dukungan daru Muhammadiyah yang semakin membuka cakrawala keilmuan bagi para murid-murid sekolah di bawah naungan SI dan Muhammdiyah. Di sisi lain pengaruh dari Al-Khairaat juga semakin menunjukkan bahwa dunia pendidikan di Buol mengalami perkembangan pesat ${ }^{23}$.

Muhammadiyah pada tahun 1932 menjadi gerbong utama pembaharuan dan modernisasi pendidikan di Buol. Mereka mulai membangun gedung sekolah melalui bantuan dari masyarakat setempat, kemudian menjalankan pendidikan yang setara dengan madrasah ibtidaiyah. Menariknya, tidak hanya persoalan pendidikan keagamaan, pendidikan profesi juga berkembang baik di Buol. Sekolah partikulir berdiri pada tahun 1917 di Paleleh, Bogo, dan Lintidu yang menjadi Bestuurs Volkschool (BVS). Dua tokoh utama seperti R. Pusadan dan S. Binol disekolahkan melalui kas Landschap Buol. R. Pusadan dikirim ke sekolah OSVIA, sedangkan S. Binol dikirim ke sekolah Haki Tinggi. Keduanya merupakan tokoh Buol yang merasakan pendidikan modern yang setara dengan pendidikan sekolah Eropa ${ }^{24}$

Dalam perkembangan pendidikan di Buol, motivasi keagamaan juga terlihat dalam berbagai gerakan nasional yang melibatkan rakyat dan kalangan terdidik. Dalam sebuah wawancara ditemukan satu informasi bahwa gerakan kalangan terdidik di Buol tidak lepas dari peran dan pengaruh para tokoh-tokoh yang ada di Sulawesi Tengah. Beberapa di antara mereka juga bahkan ikut menghadiri kunjungan H.O.S. Tjokroaminoto dan A. Muis ketika menyampaikan visi dan misi gerakan SI di Sulawesi Tengah pada tahun 1918. Terbukti ketika Buol menjadi salah satu wilayah yang mendirikan cabang SI setelah kunjungan Tjokoraminoto dan A. Muis pada masa itu.

Propaganda terhadap Islam dan kalangan terdidik dari kelompok Muslim justru menjadi benteng pertahanan kuat bagi masyarakat Sulawesi Tengah, termasuk di Buol. Gerakan pemuda terdidik di Buol diperkuat melalui pengkaderan organisasi

${ }^{22}$ Tim Proyek Inventarisasi dan Dokumentasi Kebudayaan Daerah, Sejarah Daerah Sulawesi Tengah, (Jakarta: Departemen Pendidikan dan Kebudayaan, 1984), h. 100.

${ }^{23}$ Tim Proyek Inventarisasi dan Dokumentasi Kebudayaan Daerah, Sejarah Daerah Sulawesi Tengah, (Jakarta: Departemen Pendidikan dan Kebudayaan, 1984), h. 110-116.

${ }^{24}$ Tim Proyek Inventarisasi dan Dokumentasi Kebudayaan Daerah, Sejarah Daerah Sulawesi Tengah, (Jakarta: Departemen Pendidikan dan Kebudayaan, 1984), h. 119. 

mengakomodasi pemikiran dan aktivitas para pemuda Muslim. Selain itu, mereka juga tergabung dan terkoordinasi dengan Pemuda Indonesia yang bergerak secara nasional. Dari gerakan tersebut, mereka tersadar untuk memperoleh kemerdekaan. Para anggota organisasi banyak lulusan dari sekolah desa yang hanya tiga tahun dan mendapatkan pencerahan dari organisasi yang mereka ikuti.

Di awal abad ke-20 pendidikan di Buol, termasuk pendidikan Islam, mengalami peningkatan. Masyarakat mulai memperoleh pendidikan dari organisasi Islam Muhammadiyah dengan membangun gedung sekolah. Sampai pada tahun 1913 sampai 1935 tercatat 154 murid yang merasakan sekolah pendidikan guru dan beberapa di antaranya berhasil menjadi guru untuk mengembangkan dunia pendidikan.

Praktek pendidikan berdampak pada kehidupan kesenian di Buol. Dalam sebuah sumber ditemukan bahwa buruda juga menjadi popular di Buol yang mana teks-teks buruda ini diambil dari kitab al-Barzanji. Orang-orang Buol mengkreasikan kesenian tersebut dengan menambahkan beberapa jenis tabuhan dari alat musik, baik marawis atau gambus. Terdapat juga istilah meleged atau berpantun dan bersyair yang biasanya mengandung nilai-nilai kehidupan masyarakat Buol. Seringkali tersirat pesan-pesan keagamaan dari teks meleged yang dibacakan, terutama untuk masyarakat dan penguasa, atau bahkan berupa sindiran bagi mereka yang tidak patuh pada aturan keagamaan.

\section{Penutup}

Membahas mengenai pendidikan Islam di Buol mengalami perkembangan, baik secara internal dan eksternal. Dinamika pendidikan bertumbuh dengan baik beriringan dengan kegiatan kolonialisasi yang dilakukan oleh pemerintah kololonial. Periodesasi dalam perjalanan sejarah pendidikan Buol, terutama dalam pendidikan Islam, terlihat pada pola pola pengajaran dan keterlibatan para penyebar ajaran Islam. Mereka menjadi salah satu faktor pendorong yang mengubah aspek historisitas pendidikan Islam di masa lalu.

Keterikatan pola pendidikan berdampak pada kehidupan masyarakat, budaya, dan lingkup sosialnya. Dinamika, transformasi, hingga mobilisasi terjadi mampu menggerakkan pendidikan, begitupun dengan aspek dan faktor pendukungnya. Melalui hal tersebut terjadi evolusi dalam dunia pendidikan, termasuk pendidikan Islam, di Buol. Dengan adanya tokoh organisasi dan gerakan nasionalisme membuat masyarakat Buol terlibat banyak dalam peningkatan pendidikan masyarakat. 
Selama abad ke-19 hingga awal abad ke-20 M, pendidikan di Buol masih terpengaruh dengan kondisi politik yang berkembang pada masa itu. Anak-anak dari kalangan bangsawan, dan beberapa orang dari kalangan terdidik memiliki privilase untuk memperoleh pendidikan dengan baik, sehingga mereka memilih beberapa daerah yang dekat dengan Buol untuk melanjutkan pendidikan.

\section{Daftar Pustaka}

Azra, Azyumardi, Pendidikan Islam: Tradisi dan Medernisasi Menuju Milenium Baru, Jakarta: Logos, 1999.

Azra, Azyumardi, Surau: Pendidikan Islam Tradisional dalam Transisi dan Modernisasi, Jakarta: Logos, 2003.

Azra, Azyumardi, Desember "Pendidikan Islam Di Era Globalisasi: Peluang Dan Tantangan", dalam Jurnal Penelitian Pendidikan Agama dan Keagamaan, vol. 6 No. 4 (2008.), hlm. 123-137.

Hamid, Abu, "Sistem Pendidikan Madrasah dan Pesantren di Sulawesi Selatan" dalam Taufik Abdullah ed., Agama dan Perubahan Sosial, Jakarta: CV. Rajawali, 1983.

Kawandaud, T. Tambo dan Sejarah Buol, Gorontalo: Drukkerij Annaser, 1949.

Lopez, Ariel C., 2018. "Conversion and Colonialism: Islam and Chrsitianity in North Sulawesi, c. 1700-1900”, Proefschrift ter ter verkrijging van de graad van Dotro aan de Universiteit Leiden, Filipina, Lucena City, 2018.

Majul, Cesar A., 1989. Dinamika Islam di Filipina, Jakarta: LP3ES.

Manus, L. TH., Sejarah Pendidikan Daerah Sulawesi Utara, Jakarta: P3K Depdikbud, 1980.

Nur, S. R., Beberapa Aspek Hukum Adat Tata Negara Kerajaan Gorontalo Pada Masa Pemerintahan Eato 1673-1679, Ujung Pandang: Universitas Hasanuddin, 1979.

Sadi, Haliadi, dan Syamsuri, 2016. Sejarah Islam di Lembah Palu, Yogyakarta: Q Media, 2016.

Steenbrik, Karel A., Pesantren, Madrasah, dan Sekolah: Pendidikan Islam dalam Kurun Modern, Jakarta: LP3ES, 1994.

Steenbrink, Karel A., Kaum Kolonial Belanda dan Islam di Indonesia (1596-1942), Yogyakarta: Gading Publishing, 2017.

Tacco, Richard, Het Volk van Gorontalo: Historisch Traditional Maatschappelijk Cultural Sociaal Karakteristiek en Economisch, Gorontalo: Gorontalo Drukkerij, 1935.

Tim Proyek Inventarisasi dan Dokumentasi Kebudayaan Daerah, Sejarah Daerah Sulawesi Tengah, Jakarta: Depdikbud, 1984.

Van Andel, W. J. D., Memory van Overgave, MVO, No. 39, onderafdeeling Buol, 27 Juli 1917 